\title{
The Role of Newspaper as Political Marketing Tool during Indonesian Presidential Election of 2014
}

\author{
Maslina W. Hutasuhut ${ }^{1}$, Indiana Ngenget ${ }^{2 *}$ \\ ${ }^{1}$ Faculty of Communication, IISIP Jakarta \\ ${ }^{2}$ Faculty of Political Science, IISIP Jakarta \\ Email: indiana.inge@gmail.com
}

\begin{abstract}
This research was conducted to determine the role of newspaper in implementing political marketing during Indonesian presidential election of 2014, by utilizing news contents of the presidential election from Kompas, Republika, and Media Indonesia, during campaign period. This research was conducted in three studies. Study 1 utilized quantitative content analysis to determine the objectivity of each newspaper. Study 2 utilized qualitative content analysis, using the concept of "attitude" in the discipline of consumer behavior, to determine the efforts made by each newspaper outlet in developing and altering the reader's mindset and attitude towards a presidential candidate favored by each newspaper. Study 3 utilized qualitative content analysis, using the concept and categories in political science. The research showed that the three newspapers, in various ways and methods, do not fully apply Indonesian Law No.40 of 1999 regarding Journalism Press and Journalistic Codes of Ethics as their code of conduct. These findings show that the implementation of marketing in the realm of politics must be done with caution in order to deliver news for the public in a neutral and independent manner. It can be concluded that the lack of objectivity from the three newspapers relates to the dominant ideological model theory, in which media ownership will determine the political views that would be disseminated by the mass media, as well as elite values model theory, in which the control of the media's output by means of intervention from the media owners in editorial decisions, prohibiting the editor's and journalist's professional independence.
\end{abstract}

Keywords: political marketing; presidential election; Journalistic Codes of Ethics, objectivity, factuality, impartiality.

\section{Introduction}

Presidential election is one of the indicators and parameters of how democracy rules a country in which its people actively participate in general election that provides transparency, freedom of speech as well as freedom of political expression. In a democracy, presidential election is indicated by the amount of political activities, which includes participation in a political party, lobbying, as well as conducting an election campaign in order to promote themselves to the public, and to influence them in electoral decision making. The role of mass media (including newspaper) in 2014, compared to presidential elections held in 2004 and 2009, has grown exponentially in terms of influencing the public opinion of the masses. News generated at the time of campaign was a part of each presidential candidate's political marketing, Prabowo 
Subianto - Hatta Rajasa and Joko Widodo - Jusuf Kalla. This can be seen in the relationship of media and politics, with mass media served as the campaign platform where many political views are being debated and discussed, enabling media to shape political views and attitude of the society. Freedom of the press is one of the main characteristics of a democratic government. Thus, media should play an indispensable role in the proper functioning of a democracy. However, in the 2014 presidential election, media allegedly served as presidential winning team rather than acted as democracy's gatekeeper.

The news-writing style, as mentioned above, was part of political marketing that is feared to transform from what should be noble in politics into some promotional product marketing, which can lead to money politics. Futher highlighting the fact that unethically conducted political marketing will violate the democracy. Mass media reports that were analyzed in this study were Kompas, Republika and Media Indonesia at the time of campaign period from June 4 to July 5, 2014, in order to analyze the effort of political marketing done by the three newspapers that violated Indonesian Law No. 40 of 1999 about Press and Journalistic Code of Ethics, by analyzing the objectivity of those newspapers, effort of political marketing in shaping and changing voters' attitude, and factors behind the report of the three newspaper.

\section{Literature Review}

\subsection{Presidential Election in the context of Democracy}

In a modern democratic government system, presidential election is a manifestation of democracy itself. Democracy is a concept that composed of the Greek words demos (people) and kratos (power), and is a system of government in which the power is in the hand of the people. One of the main characteristics of democracy is political equality where the power of politics should be distributed as evenly as possible. The democratic method is that institutional arrangement for arriving at political decisions in which individuals acquire the power to decide by means of a competitive struggle for the people's vote (Schumpeter, 2013), that is fair voting procedure that held at regular intervals to choose the head of the country (Ishimaya et al, 2013).

\subsubsection{Political Socialization and Mass Media}

Political socialization is a part of socialization process that specifically form people's political values, which direct society to participate in its political system. Rush (1992) defined political socialization as a process in which individuals in a given society become acquainted with the political system so that it determines their perceptions and their reactions to political phenomena. According to Chilcote (2010), there are two types of agents of socialization, which are primary (family and school) and secondary (mass media). Political socialization is part of process in which people form their political attitude and behavior. Attitude is defined as an enduring predisposition to behave consistently in a favorable or unfavorable manner with respect to a given object (Schiffman \& Kanuk, 2010).

\subsection{Marketing and Political Marketing}

As stated by Hunt (1983) and Kotler \& Levy (1969) regarding broadening the concept of marketing that is not only focused on business activity or limited to product/services, the concept of marketing is also applied in a political marketplace called Political Marketing. 
Segmentation is necessary to determine a party's work plan, especially on how they should communicate and build interaction with public in a form of political message, work programs, political campaign, socialization and political product (Firmanzah, 2012). In a market oriented approach, the party is able to identify problems faced by society as a source to plan their work programs (Firmanzah, 2012). The intended target market is a set of segmented voters, subject to positioning, by putting the candidate in favorable light in the mind of the voting public. Positioning can be applied to the three components that form attitude: cognitive, affective and conative (Schiffman and Kanuk, 2010). Cognitive component involves knowledge and perception gained from direct experience with candidate as well as information from various sources that will shape a viewtowards presidential candidate. Affective component is emotions/ feelings consumers have towards the presidential candidate while conative is consumer's tendency to vote for that candidate. The interaction between cognitive, affective and conative will create a positive/negative attitude about a presidential candidate; after the positive attitude is established, voters will be likely to choose that particular candidate.

Political marketing effort in newspaper is performed by constructing the news that will form knowledge and trust towards candidate covered by the media; creating positive feelings which will eventually build the public's intention to vote for the candidate favored by the newspaper. Aside from creating positive attitude, political marketing effort in news reporting is also done in a way to alter attitude towards presidential candidate favored by certain newspaper by : 1) changing the basic motivational function; 2) associating object (in this case is presidential candidate) with certain reference group/event/the cause of event; 3 ) resolving two conflicting attitudes; 4) altering components of the multi attribute model; 5) changing consumer belief about brand (in this case, the party's brand personality and presidential candidate) (Schiffman \& Kanuk, 2010).

In its development, political marketing has evolved from a mere communication tools to become an integrated way of managing politics, policy development, campaign, or even governing (Kotler, 1975 in Vancov, 2013) that overviews the adopted flow chart, information, goods and services as well as communication from business marketing process to political marketing as the development of broadening concept of marketing (Kotler, 1969) (Figure 1):

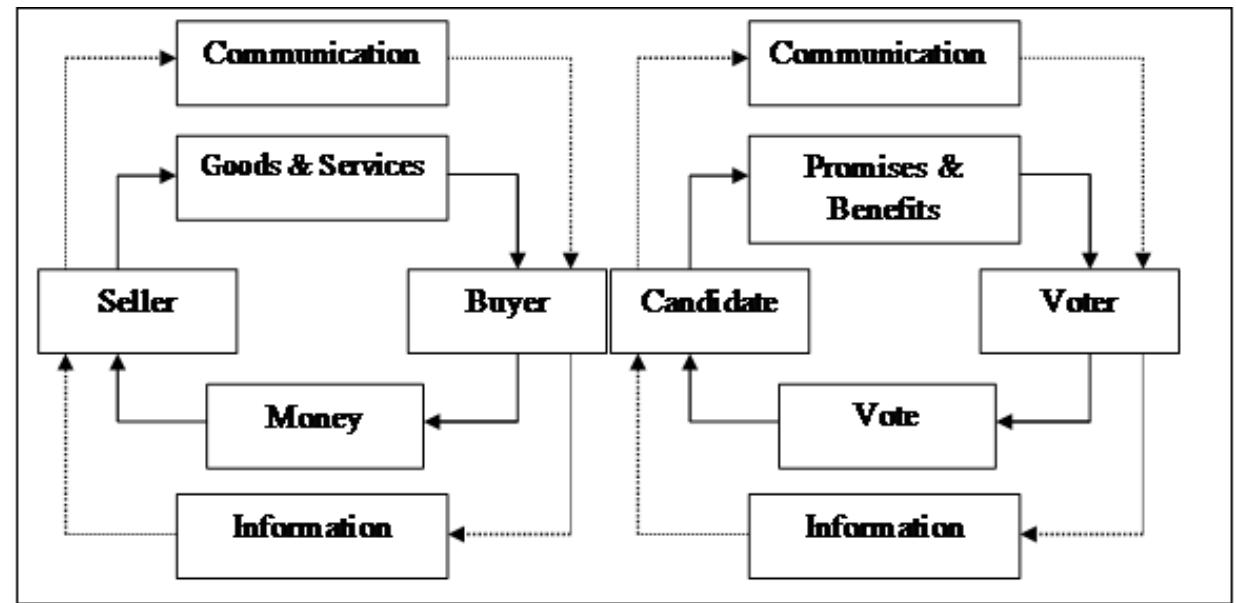

Source: Kotler, 1975, inVancov, 2013

Figure1. Comparison of Marketing and Political Marketing 
Candidate sends out his political communication to the voting public by stating their political promises. Communication process from candidate to voter is political communication in a form of open campaign or media coverage deliberately aimed to build/change the voter attitude into a positive one towards certain candidate. If the influence of political communication is able to create positive attitude towards candidate, then there is a tendency that the voter will cast their vote for that candidate. Political campaign is similar to a new product campaign or in a wider scope, it is brand activation in a marketing sphere. In political marketing that utilizes marketing instrument, the effectiveness is questionable because it may harm democracy and cause misinterpretation. Shaughnessy, 1990 (Vancov, 2013), pointed out that the negative impact regarding political marketing implementation depends on the view on democracy.

\subsubsection{Newspaper Campaigns as Political Marketing Tool}

Newspaper campaigns in 2014 election were very dynamic. Both candidates did numerous political marketing strategy to gain as many votes as possible. The form of campaigns are open debates and the distribution of campaign materials through printed media (Decree Letter of General Election Commissions No 35 of 2004). Media coverage of Kompas, Republika and Media Indonesia regarding electoral campaign in the period of June 4 to June 5 2014, was identified as news focused on problems relating to the election itself. Problems such as: the hope that the presidential election is running fairly and decently, the integrity of the candidates, the transparency of campaign funds, winning strategy, supporting party, politic socialization covering the role of media (online-printed), the integrity of the General Election Commissions (KPU), Fixed Voters List (DPT), voting recapitulation, the integrity of election administrator, electoral fraud, campaign violation and the electability of the candidates that based upon the result of polling organizations. Communication done by the media resulted as media effect to its readers.

In various research in mass communication, message or media content has been seen as silver bullet shot to the mind of its audience, therefore in Social Action Theory, it is described as the intention of the sender, the message content and receiver's interpretation (Anderson \& Meyer, 1980). Differ from Social Action theory of Anderson and Meyer, Hoeta Soehoet (2002) explained the process of deeper communication process by revealing the sender and receiver internal factor in processing and receiving the message content. Both Anderson and Meyer and Hoeta Soehoet stated that public actively participates in communication through media so public builds their understanding of a message they perceived.

In contrast to direct effect of media model to public, in Agenda Setting theory, mass media set the topics for their audience to build public opinion (Kaid, 2015). Media agenda has a broad scope, it can be used to convey various media function such as information, education and entertainment, as well as to build like or to dislike attitude toward an object according to owner's interest and or decision maker of the media.

From dependency side, the main idea of Media Dependency theory (Ball-Rokeach \& DeFleur, 1976) is public dependency on the media to get their desired information, whereas media is trying to create public dependency on the media by creating need, interest and public personal motivation. From the media effect theories above, it is clearly indicated that there will always be influence of message content from the media to its audience. 


\subsubsection{Press Regulation and Journalistic Code of Ethic}

Press in Indonesia is regulated by Indonesian Law no. 40 of 1999, that regulates Press in terms of its principles, function, rights, obligation and roles; regulates journalist in terms of their freedom to be part of organization, obligations to comply the Journalistic Code of Ethic (Kode Etik Jurnalistik/KEJ),to guarantee and to protect the rights for journalist to do their job; regulates press company, the formation of Press Council; the role of society in developing the freedom of press and to guarantee society to acquire information. Articles in Journalistic Code of Ethics related to this research is article 1 (striving for independent, accurate, balance, and good will); article 3 (testing information, balance reporting, and separating facts from opinion); article 4 (does not write false news and slander); article 8 (does not write news based on prejudice or discrimination).

Press performance can be measured based on various parameters. One of them is based on Objectivity concept. Objectivity is a form of media practice in gathering, processing and spreading information through media that should be persistent and neutral toward object covered where journalist should ignore subjectivity or involve personal opinion in their coverage (McQuail, 2000). The definition of objectivity is aligned with Journalistic Code of Ethic article 1, 3, 4 and 8.

According to McQuail (2000) and Rahayu (2006), the concept of objectivity consists of Factuality and Impartiality dimensions. Factuality dimension is measured by five variables: Factualness (attributes: main point, information value, readability and check ability), Accuracy (attributes: source, news verification, and accuracy), Completeness (attributes $5 \mathrm{~W}+1 \mathrm{H}$ ); Normative Theory (attributes: representing public interest, representing values in society) and Journalistic Practice (attribute: timeliness, prominent, magnitude, real world). Impartiality is measured by two variables: Proportional Access \& Even-Handed Evaluation (attributes: balance coverage, neutral and no stereotyping) and also Non-Sensational (non-sensationalism, non-juxtaposition and non-linkage)

\subsection{Media and Politic}

The concepts regarding media relation and politic are categorized based on different views of the politics' effect of media, where the concepts that are relevant in this study are dominant ideology model and elite value model. Dominant ideology model portrays mass media as a politically conservative power, that in accordance with the interest of socio \& economic elites and has role in promoting the political willingness and passiveness amongst the society. Gramsci's idea (in Chomsky, 2004) stated that media has done propaganda to promote borjuisme and encourage capitalist hegemony, to serve the interests of large companies and elite media. Media ownership will determine political views and other views disseminated by the mass media (Heywood, 2014).

In elite values model, there has been an emphasis on the control mechanism of media output. This view suggests that editors, journalists and broadcasters do not own significant professional independence, and can be intervened by media owner in editorial decisions, therefore the media's political bias reflects the values of majority groups amongst its professionals (Heywood, 2014). 


\section{Research Methodology}

Research Object of this study is News of presidential election campaign from June 4th to July 5th, 2014 taken from Kompas, Republika, and Media Indonesia. These media were chosen since those newspapers are all national-based media. Berrelson, 1952 (in Eriyanto, 2011) stated that content analysis is one of the research technique that are done objectively, systematically, and descriptively quantitative from manifested communication content. While Holsti and Weber, 1969 (in Eriyanto, 2011) stated that content analysis is one of the research technique to create inference that is done objectively, and conduct identification systematically from message's characteristic. The Study 1 was done using Quantitative Content Analysis method while the study 2 and study 3 were done using Qualitative Content Analysis method.

Table 1. Stages of Content Analysis in This Study

\begin{tabular}{|c|c|c|c|}
\hline & Study 1 & Study 2 & Study 3 \\
\hline Population & $\begin{array}{l}\text { - Kompas: } 193 \text { news } \\
\text { - Republika: } 155 \text { news } \\
\text { - Media Indonesia: } 162 \text { news. }\end{array}$ & $\begin{array}{l}\text { - Kompas: } 193 \text { news } \\
\text { - Republika: } 155 \text { news } \\
\text { - Media Indonesia: } 162 \text { news. }\end{array}$ & $\begin{array}{l}\text { - Kompas: } 193 \text { news } \\
\text { - Republika: } 155 \text { news } \\
\text { - Media Indonesia: } 162 \\
\text { news. }\end{array}$ \\
\hline Sample & $\begin{array}{l}\text { - To test the reliability and validity of } \\
\text { measuring instrument: } 5 \% \text { from the } \\
\text { population of news from each news- } \\
\text { paper. } \\
\text { - To analysis the category test: } 25 \% \\
\text { from population after reducing the } \\
\text { samples of reliability and validity } \\
\text { test. }\end{array}$ & $\begin{array}{l}5 \text { news from each newspaper that are } \\
\text { limited to news that contains dimensions } \\
\text { of impartiality. } \\
\text { Used the dimension of Impartiality } \\
\text { because what will be examined is the } \\
\text { formation and change of the reader's } \\
\text { attitude from one of the presidential } \\
\text { candidates to another presidential } \\
\text { candidate. }\end{array}$ & $\begin{array}{l}\text { - Kompas: } 14 \text { news } \\
\text { - Republika: } 15 \text { news } \\
\text { - Media Indonesia: } \\
\text { news. }\end{array}$ \\
\hline $\begin{array}{l}\text { Sampling } \\
\text { method }\end{array}$ & Simple Random Sampling & $\begin{array}{l}\text { Purposive Sampling. } \\
\text { This sampling is a sampling technique in } \\
\text { which researcher relies on his or her own } \\
\text { judgment when choosing members of } \\
\text { population to participate in the study. }\end{array}$ & Simple Random Sampling \\
\hline $\begin{array}{l}\text { Analysis } \\
\text { method }\end{array}$ & $\begin{array}{l}\text { Validity test and reability test used } \\
\text { Biserial Correlation and Kuder } \\
\text { Richarson - } 20 \text { (KR-20). These } \\
\text { methods were chosen due to the } \\
\text { questionnaire's form in binary data. } \\
\text { - Category test used frequency } \\
\text { descriptive statistics. The measure } \\
\text { category throught each atribute as } \\
\text { descripbing in literatur rivew page 5. }\end{array}$ & $\begin{array}{l}\text { Qualitative Analysis method in contextual } \\
\text { unit by word/sentence comparison with the } \\
\text { change of attitude theory by Schiffman } \\
\text { Kanuk. }\end{array}$ & $\begin{array}{l}\text { Qualitative Analysis method } \\
\text { in contextual unit to acquire } \\
\text { insight of news content } \\
\text { from political science's } \\
\text { side. }\end{array}$ \\
\hline
\end{tabular}

Table 2. Mean of Frequency of Factuality Categorys

\begin{tabular}{|c|c|c|c|c|c|c|c|}
\hline \multirow[t]{2}{*}{ Dimension } & \multirow[t]{2}{*}{ Observed Variable } & \multicolumn{2}{|c|}{ Kompas } & \multicolumn{2}{|c|}{ Republika } & \multicolumn{2}{|c|}{ Media Indonesia } \\
\hline & & $f(\%)$ & Rank & $\mathrm{f}(\%)$ & Rank & $f(\%)$ & Rank \\
\hline \multirow{5}{*}{ Factuality } & Factualness & 89,9 & 2 & 91,0 & 1 & 89,4 & 3 \\
\hline & Accuracy & 92,9 & 2 & 90,1 & 3 & 95,1 & 1 \\
\hline & Completeness & 69,7 & 1 & 67,6 & 2 & 43,9 & 3 \\
\hline & Normative Theory & 78,8 & 1 & 74,2 & 2 & 69,5 & 3 \\
\hline & Journalistic Practice & 73,5 & 1 & 67,6 & 2 & 56,7 & 3 \\
\hline \multirow{2}{*}{ Impartiality } & $\begin{array}{l}\text { Equal \& Evenhanded } \\
\text { Evaluation }\end{array}$ & 66,7 & 1 & 64,3 & 2 & 42,3 & 3 \\
\hline & Non-Sensational & 75,8 & 2 & 81,1 & 1 & 70,8 & 3 \\
\hline
\end{tabular}




\section{4. $\quad$ Results}

Study 1: In this paper, we define the measurement by dividing frequency of percentage into three categories: "not good": $0<\mathrm{f} \leq 3.33$, "medium": $3.33<\mathrm{f} \leq 6.67$ and "good": $6.67<\mathrm{f} \leq 100$. Table 2 shows "good" result in the factualness category for Kompas and Republika, however Media Indonesia have been given "medium" result in completeness category and journalistic practicality. For these three categories: Impartiality, equal and even-handed evaluation and non-sensational all of the three newspapers get "medium" result.

Study 2: Politic-marketing through Kompas, Republika and Media Indonesia in the campaign period shows there have been word selection, repetition and emphasis in an attempt to favor a presidential candidate that they supported. This analysis is done specifically for the impartiality dimension consisting of categories thatmeasureimpartiality, neutrality of news, non-stereotyping and non-public opinion through: non-fact \& non-sensational news, association effect and dramatic effect. The findings also reveals that there are some deliberations in building positive attitudes through cognitive, affective and behavioral to presidential candidate. In addition, attitude development is also done by changing positive attitude to be negative or vice versa, by changing the basic motivation on voting president, such as an associate candidate with a certain group, claiming a candidate won via media, and the most commonly used method of changing the audiences' belief and viewpoint of good candidate and bad candidate. This analysis is matched and proven in both quantitative and qualitative descriptions, as well as proven in specific qualitative assessment on impartiality dimension for developing and changing attitude by the newspapers.

Study 3: Result of qualitative analysis on news objectively shows that in presidential election, 2014: Media Indonesia's news is unbalanced and not neutral, specifically because it has developed public opinion with associative linkages and directed public opinion with dramatic, sensational and stereotyping effect. Kompas is generally balanced and neutral, even though it also developed public opinion and directed public opinion with dramatic, sensational and stereotyping effect, but it is not dominant. Republika is generally also balancde and neutral. Similar to Kompas, it also develop public opinion and directed public opinion with dramatic, sensational and stereotyping effect, but it is also not dominant. In political science perspective, the three newspapers, Kompas, Republika and Media Indonesia have a big role to influence and to build or change voters' favorability in presidential election 2014 which was won by Joko Widodo-Jusuf Kalla. Specifically, all the three newspapers have high relevance with categories or political dimension, i.e. the integrity figure of each candidate, which plays an important role to gain voters' sympathy. News about candidate campaigns such as open campaign, visits, etc. is designed with a specific communication strategy to form an emotional bond with voters (with social, cultural, ideology, and religious approach). In general analysis, news background for these three major newspapers have high relevancies with political impact from media i.e. dominant ideology model and elite value model. First, media ownership and business interests of the owners' corporation will define political views spread by the media. Second, media output control mechanism, editor, journalist and newscasters are easily intervened by the owner due to lack of professionalism. In relation with unbalance and un-neutral news for Media Indonesia driven by the fact that the owners support Joko Widodo-Jusuf Kalla. Dominant ideology model and elite value model explained the position of Kompas and Republika, especially Media Indonesia, which is not independent and not objective on their news throughout the campaign periods. In this research, media's ownership factors will determine the news output and become 
un-independent and not objective, and consequently build and change voters' attitudes towards the candidate. Marketing politic news of Kompas, Republika and Media Indonesia can be proven in this research.

\section{Discussion}

Media according to Sudibyo (2001) is not only the means of conveying a message to a neutral audience. The media can actually construct and define reality to be disseminated to audiences. In this case, there are two roles of media. Firstly, media as sources of power that control the consciousness of audiences (Hall, 1982), and secondly the media as sources of justification. Those who control the media can construct the reality into shaped reality. The role played by the media can be done through the news, so that the audience (the reader) unconsciously formed his consciousness without being forced. News is a reflection or a reflection of reality so the news must reflect the real reality. Therefore, journalists in covering and writing the news must explain the news or events as they are. In addition, journalists in the coverage are required to be balanced and neutral.

Referring to the results of research, Kompas, Republika and Media Indonesia conducted political marketing by ignoring the dimension of impartiality.

In terms of politics, unbalanced and unneutral reporting factors of Kompas, Republika and Media Indonesia is due to the media ownership factor correlated with the mechanism of output control of the media, that is the editorial decisions can be intervened by the interests of politics and ideology of media owners.

\section{Conclusion}

The results showed that the three newspapers violated the Law of the Republic of Indonesia Act Number 40 year 1999 on the Press and the Journalistic Code of Ethics. Violation is done on the dimension of impartiality, which is deliberately conducting a campaign that favored the nominated candidate and harmed the potential opponent. As in commercial marketing, campaigns are carried out as a brand activation candidate and de-marketing in unseeded candidates. News is written according to target audience characteristics, as well as the media's positioning.

Quantitative research results obtained the ranking of newspaper objectivity as follows: Ranked 1: Kompas; Ranked 2: Republika; and Ranked 3: Media Indonesia. In addition, the ranking of newspapers studied by category as measured by the results: 1. Kompas newspaper: 1 category: Equal \& Even-handed Evaluation predicated not good; 2. Republika newspaper: 1 category: Equal and Even-handed Evaluation predicated not good; 3. Media Indonesia newspaper: 3 categories: Completeness, Journalistic Practices, and Equal \& Even-handed Evaluation are not well predicated.

By analyzing qualitative content to the results of quantitative content analysis, it was found that the three newspapers had violated Law of the Republic of Indonesia Act Number 40 year 1999 on the Press and the Journalistic Code of Ethics (PWI) with the level of violations that correlated with the findings of the analysis quantitative content. 
In terms of political marketing through Kompas, Republika and Media Indonesia during the presidential campaign period, it can be seen that the three newspapers did perform word selection and, repetition, emphasizing as their efforts to favor the presidential candidate they supported. This analysis is conducted specifically for the dimensions of impartiality consisting of categories that measure impartiality, neutrality of news, non-stereotyping, non-public opinion through non-sensational facts, association effects on two or more event, as well as the dramatic effect on two or more inconsistent events.

From the research findings, apparently there are efforts to deliberately build a positive attitude through cognitive, affective and behavioral level against the presidential candidates who are favored and supported by each newspaper.

Moreover, there are also efforts to change attitude towards presidential candidate by changing the positive attitude to be negative. On the contrary, to support their favored candidate by changing the basic function of electing president, associating the candidate to referred group according to the newspapers' interests, claiming that supported candidate will resolve two opposite stances, and the most widely used method of changing the belief and viewpoint of audiences from either being unkind to a candidate who were not supported by the newspaper. From quantitative content analysis research and qualitative descriptions, it is appropriate, as well as with the results of a special quantitative analysis of the impartiality dimension very congruent with findings on qualitative content analysis for the development and change of public attitudes by newspapers.

In identifying the objectivity of news coverage, Kompas, Republika and Media Indonesia, in general Media Indonesia news are very unbalanced and not neutral, especially from the development of opinion readers with associative linkages effects and the direction of the reader's opinion with dramatic effects. There are sensational elements and stereotypes in the news covered by Media Indonesia. News covered by Kompas is generally balanced and fairly neutral, although there's a development of reader opinions with associative linkages effects and there are directed opinions of readers with dramatic effects, there were also sensational elements and stereotype but not dominant. News covered by Republika in general is quite balanced and quite neutral despite the development of reader opinions with associative linkages effects and there is a briefing of reader opinions with dramatic effects, there were also sensational elements and stereotype but not dominant. The connection with unbalanced and un-neutral coverage on Media Indonesia can be inferred because of the background of Media Indonesia's ownership of the proponents of Joko Widodo-Jusuf Kalla.

A general analysis of the background factors of three newspapers as the main source of data in content analysis is Kompas, Republika and Media Indonesia has relevance to theories about the political impact of the media: the dominant ideological model and the model of elite values. First, the ownership of the media and the business interests of the owner company will determine the political views and other views disseminated by the mass media; Secondly, the mechanism of media output control, i.e. the positions of editors, journalists, and broadcasters do not have significant professional independence, which may be interfered by media owners in editorial decisions, therefore the political bias of the media reflects the values of the majority group from The professionals.

It can be concluded that there was a political marketing effort by the above mentioned newspapers which against the Law of the Republic of Indonesia Act Number 40 year 1999 on the Press 
and the Journalistic Code of Ethics and they ignored The General Election Commission (KPU) Regulation number 16 year 2014 on the Presidential an Vice Presidential election campaign, particularly on the campaign through mass media. In the regulation of KPU, the Press Council should be able to impose sanctions in accordance with the authority possessed and regulated in the laws governing the press. The Press Council suggested to exercise strict supervision, as well as the Indonesian Journalists Association, in order to achieve the function of the Press as a guardian of democracy. As a new discourse, it is necessary to consider the regulation of media ownership by party officials. Then the suggestions for election-related institutions, The General Election Commission (KPU) and the Election Supervisory Board (Bawaslu) should optimize their functions and roles as independent organizers and election supervisors, so that the election can run in an direct, public, free, confidential, open, honest and fair manner.

\section{References}

Anderson, James A, and Timothy P. Meyer. (1980). Mediated Communication: A Social Action Perspective. Newbury Park. CA: Sage.

Ball-Rokeach, Sandra J, and DeFleur ML. (1976). "A Dependency Model of Mass-Media Effects". Communication Research. 3 (1): 3-21.

Chilcote, Ronald H. (2010). Teori Perbandingan Politik. Jakarta: PT. RajaGrafindo Persada. Chomsky, N (2004). Hegemony and Survival: America's Global Quest for Dominance (The American Empire Project). New York: Owl Books.

Eriyanto. (2011). Analisis Isi, Pengantar Metodologi Untuk Penelitian Ilmu Komunikasi dan Ilmu-Ilmu Sosial Lainnya. Jakarta: Kencana Prenada Media Group.

Firmanzah. (2012). Marketing Politik: Antara Pemahaman dan Realitas (Edisi Revisi). Jakarta: Yayasan Pustaka Obor Indonesia.

Heywood, Andrew. (2004). Politik (edisi keempat). Yogyakarta: Pustaka Pelajar.

Hoetasoehoet. (2002). Teori Komunikasi. Jakarta: Yayasan Kampus Tercinta.

Hunt, Shelby. D. (1983). General Theories of the Fundamental Explananda of Marketing, Journal of Marketing, 47.

Ishimaya, John T, Breuning, Marijke (Editor). (2013). Ilmu Politik Dalam Paradigma Abad ke-21 Sebuah Referensi Panduan Tematis.Jakarta: Kencana Prenada Media Group.

Kaid, Lynda Lee. (2015). Handbook penelitian Komunikasi Politik. Bandung: Penerbit Nusa Media.

Kotler \& Levy. (1969). Broaden the Concept of Marketing. Journal of Marketing, 33. McQuail, Denis. (2000). Mass Communication Theory, London: SAGE Publications Ltd. Mas'oed, Mohtar, MacAndrews Colin. (2001). Perbandingan Sistem Politik, Yogyakarta: Gadjah Mada University Press. 
Rahayu. (2006). Menyingkap Profesionalisme Kinerja Surat Kabar di Indonesia. Jakarta: Pusat Kajian Media dan Budaya Populer, Dewan Pers, dan Departemen Komunikasi dan Informasi.

Rush. (1992). Politics and Society: An Introduction to Political Sociology, Hemel Hempstead: HarvestWheatsheap.

Schiffman \& Kanuk. (2010). Consumer Behaviour, Pearson Education,.Inc. Prentice Hall, Upper Saddle River.

Schumpeter, Joseph A. (2013). Capitalism, Socialism \& Democracy, Yogyakarta: Penerbit Pustaka Pelajar.

Sudibyo, Agus. 2001. Politik Media dan Pertarungan Wacana. Yogyakarta: LKiS.

Vancov, Nikolay. (2013). The Strategic Dimensions of Political Marketing. Economic Alternatives, Issue 3.

Undang-Undang Pers No. 40 tahun 1999 tentang Pers Kode Etik Jurnalistik Persatuan Wartawan Indonesia Undang-Undang KPU No. 16 tahun 2014. 